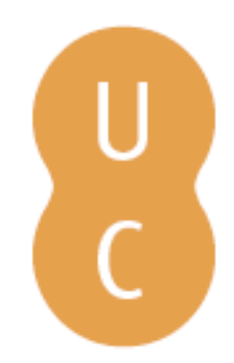

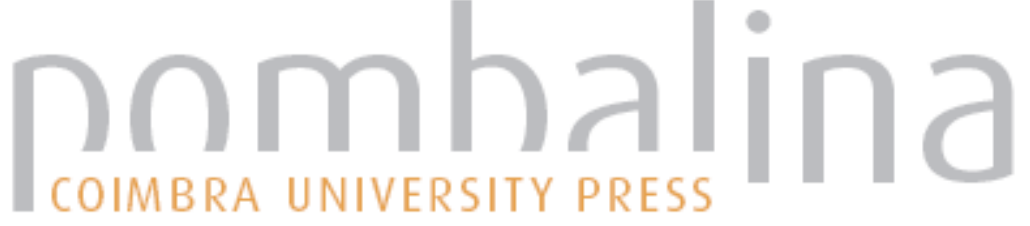

\section{Las religiones del libro monoteismo(s) y fundamentalismo(s)}

Autor(es): José Tamayo, Juan

Publicado por: Imprensa da Universidade de Coimbra

URL

persistente: URI:http://hdl.handle.net/10316.2/30085

DOI: $\quad$ DOI:http://dx.doi.org/10.14195/978-989-26-0310-0_3

Accessed : $\quad$ 26-Apr-2023 11:20:38

A navegação consulta e descarregamento dos títulos inseridos nas Bibliotecas Digitais UC Digitalis, UC Pombalina e UC Impactum, pressupõem a aceitação plena e sem reservas dos Termos e Condições de Uso destas Bibliotecas Digitais, disponíveis em https://digitalis.uc.pt/pt-pt/termos.

Conforme exposto nos referidos Termos e Condições de Uso, o descarregamento de títulos de acesso restrito requer uma licença válida de autorização devendo o utilizador aceder ao(s) documento(s) a partir de um endereço de IP da instituição detentora da supramencionada licença.

Ao utilizador é apenas permitido o descarregamento para uso pessoal, pelo que o emprego do(s) título(s) descarregado(s) para outro fim, designadamente comercial, carece de autorização do respetivo autor ou editor da obra.

Na medida em que todas as obras da UC Digitalis se encontram protegidas pelo Código do Direito de Autor e Direitos Conexos e demais legislação aplicável, toda a cópia, parcial ou total, deste documento, nos casos em que é legalmente admitida, deverá conter ou fazer-se acompanhar por este aviso. 


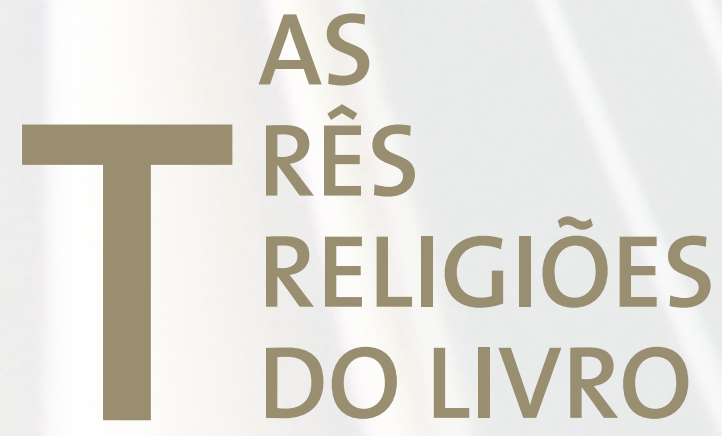

Anselmo Borges

João Gouveia Monteiro

COORDENAÇÃO 
Esther Mucznik ${ }^{13}$

\section{O MONOTEÍSMO CONDUZ AO \\ FUNDAM E NTALISM O?}

A profissão de fé fundamental do judaísmo começa assim:

"Shema, Israel, Adonai Elohenu, Adonai Ehad....Ouve Israel, o Eterno é o nosso Deus, o Eterno é um”.

Esta oração, que vem no Deuteronómio, proclama a fé a um Deus único e permanece até hoje o núcleo central da liturgia judaica, repetida duas vezes por dia e em todos os momentos dolorosos da vida, ou às portas da morte.

A fé monoteísta tem uma longa história. Não nasce de um momento para o outro. É uma lenta maturação que terá começado com Abraão, continuado com Moisés e que só aparece claramente expressa no Deuteronómio: "Só o Eterno é Deus; não há nenhum outro além d'Ele." (Deut. 4, 35)

A história da ideia monoteísta confunde-se com a própria formação do judaísmo, é o seu núcleo duro. E o judaísmo não é o produto de uma única revelação num determinado momento. É uma lenta construção colectiva que dura mais de um milénio e que é atravessada por um duplo movimento: um movimento geográfico que acompanha as migrações de um grupo humano, os hebreus, da Mesopotâmia até Canaan, e um movimento espiritual do politeísmo ao monoteísmo. É esta aventura espiritual que nos é contada na Bíblia, que permanece o texto fundador da nossa cultura.

13 Vice-Presidente da Comunidade Israelita de Lisboa. 


\section{"Eu Sou Aquele Que Sou..."}

O monoteísmo representa uma revolução profunda da espiritualidade humana. Como diz o historiador de religiões Jean Bottero:

"O povo que durante mil anos viveu e escreveu essas obras múltiplas, coligidas em seguida na Bíblia, deixou-nos acima de tudo esta ideia, que é o primeiro a ter descoberto e proclamado e depois, finalmente, imposto, da Unicidade e Transcendência absolutas de Deus: sem dúvida a concepção do nosso espírito mais contra a corrente da nossa tendência natural, que mais nos ultrapassa, que mais nos eleva acima de nós próprios, e que, por essa mesma razão, merece a nossa estupefacção, a nossa admiração, o nosso aplauso."

Um conceito que rompe radicalmente com a visão antropomórfica anterior: não é mais um deus à imagem do homem, mas o homem que aspira ser à imagem de Deus. Um Deus absoluto, transcendente, cujo único atributo é o ser "Eu sou Aquele que sou", determinando a procura incessante para desvendar o mistério divino e o impulso à perfeição, ao absoluto, ao bem. O homem criado à imagem e semelhança de Deus significa essa aspiração ardente a "imitar" Deus, no sentido de Martin Buber, ou seja, percorrendo os Seus caminhos, aperfeiçoando a obra divina.

Deus misterioso e transcendente, revela-se através de um código de conduta moral: "Amarás o teu próximo como a ti mesmo", diz o Levítico no cap. 19, versículo 18, sintetizando a essência dos Dez Mandamentos, ou as Dez Palavras (Haseret Hadiberot), como nós dizemos em hebraico. Palavras fundadoras de uma nova ordem ética universal. É o nascimento da consciência que Hitler tanto abominava dizendo "É preciso matar o judeu em cada um de nós".

Na realidade, esta é outra inovação fundamental: a moralização da religião, ou seja, a inserção de um comportamento recto e justo na prática da religião. O culto ao sobrenatural já não se satisfaz de sacrifícios e oferendas, antes exige uma vida e um comportamento conforme um código ético. 


\section{"O Monoteísmo é um Humanismo"}

Na essência, o Cristianismo e, mais tarde, o Islão retomam a fé monoteísta. No coração das três religiões encontra-se o duplo mandamento de amar Deus e de amar o próximo. Com caminhos diferentes e com palavras diferentes, a preocupação da ética, da bondade e da justiça está presente nas três. E, no entanto, a história das suas relações tem sido escrita demasiadas vezes com sangue e violência.

Não pretendo, nem é o objectivo desta comunicação, fazer um estudo comparativo das três religiões monoteístas. Pretendo, sim, dar o meu contributo na resposta à questão sugerida nesta mesa redonda: pode a ideia monoteísta ser geradora de violência? Dito de outra maneira: pode a fé num Deus único e universal ser geradora de intolerância e opressão?

Shmuel Trigano, filósofo judeu, no seu livro intitulado "O monoteísmo é um humanismo", defende uma ideia interessante: a de que é o segredo, o mistério da sua origem, que é a garantia da liberdade do homem. Por outras palavras, pode o homem, graças aos imensos progressos, nomeadamente da genética e da biologia, tornar-se dono das suas origens sem destruir a sua humanidade?

Segundo Trigano, vivemos uma época em que a ambição de criar um "homem novo", que foi a essência das ideologias políticas modernas e que, muito mais do que um sonho de libertação, representou uma forma de poder, de tentativa de uniformização violenta e opressiva, essa ambição corre hoje o risco de se tornar realidade, graças à nova genética. "O poder que o saber lhes confere (aos cientistas) pode conduzi-los, mesmo involuntariamente, a profanar o santo dos santos da identidade humana, a secar a fonte absoluta da liberdade de que é essencialmente tributária.”

Qual o verdadeiro perigo? O da supressão da diversidade e, sobretudo, da alteridade, a programação massificada do destino humano.

Alguns pensadores vêem no monoteísmo o modelo por excelência da vontade de poder e da intolerância, a raiz do totalitarismo, o inimigo da diversidade e da diferença. Como se a unidade do Deus único fosse a base de uma opressão angustiante, não deixando ao homem nenhum espaço de liberdade, como se o homem fosse aniquilado por uma divindade tanto 
mais imperial e totalitária que é única, da qual não se pode escapar, nem "temperar" com outros deuses.

Segundo Trigano, é precisamente o inverso: o monoteísmo definindo Deus tanto pela Unicidade como pela sua qualidade de Criador, terminando a sua obra no momento da criação do homem, assegura a este a liberdade de a completar e aperfeiçoar (ou não). O homem é assim, desde o seu nascimento, o parceiro de Deus na obra de criação e, sobretudo, da sua própria criação. Nesse sentido ele é livre, "à imagem” de Deus.

\section{Deus único é plural}

$\mathrm{Na}$ realidade, é a interpretação dos conceitos que é determinante. A oração judaica contém um texto que repete: "Deus de Abraão, Deus de Isaac e Deus de Jacob..." Por que não dizer simplesmente: Deus de Abraão, de Isaac e de Jacob, em vez de repetir três vezes a palavra Deus? É porque Deus único é plural, um Deus vivo, dando a cada um a liberdade de criar a sua própria relação com o divino. A violência e a intolerância vêm da leitura integral, fundamentalista e imutável, da palavra esclerosada. Vêm da convicção (ideológica e não teórica) de se possuir a única interpretação "justa" e "verdadeira" da palavra divina e de a querer impor aos outros.

A história tem-nos mostrado tragicamente que há coisas mais importantes do que a procura da verdade: a liberdade, a democracia, a livre escolha de cada um, a livre aceitação de certas regras, a acção e, do ponto vista religioso, o questionamento activo do texto sagrado, o conflito de interpretações.

"Nunca perguntes o caminho a quem já o sabe, porque nunca te poderás perder", dizia o Rabi Nahman de Braslav. É que perder-se é também procurar novos caminhos, é olhar com um olhar novo, é redescobrir, é questionar, aceitar questionar as próprias certezas, é aceitar que a sua própria finitude seja completada pela finitude do outro.

Mais do que a procura da "verdade", é preciso compreender a religião em termos de sentido. Ser judia, para mim, não quer dizer que detenho a verdade, mas sim que dou um determinado sentido ao mundo. Como judia, 
invisto o mundo de um significado que se chama Torá, Talmude, que me é transmitido pelas nossas tradições, pela nossa memória, mas reconhecendo aos outros a legitimidade e a validade de opção por outro caminho.

\section{Essência do fundamentalismo religioso}

O fundamentalismo nada tem a ver com o monoteísmo. O fundamentalismo é a transformação da religião em ideologia.

Há pessoas que, em jeito de provocação, dizem: "eu sou fundamentalista, porque respeito os fundamentos". Mas convém não banalizar os conceitos e as palavras têm um significado próprio que convém não confundir. Hoje, o fundamentalista religioso não é aquele que se limita a respeitar os fundamentos.

É evidente que há diferenças profundas entre o fundamentalismo cristão, muçulmano ou judaico. Mas, independentemente das diferenças, existem alguns traços comuns que interessa realçar:

O fundamentalista religioso é, em primeiro lugar, aquele que considera que a origem de todos os males está no abandono dos preceitos e das práticas "originais", "autênticas", da mensagem inicial, da herança revelada. E, portanto, recomenda a necessidade de retorno à observância rígida dos preceitos, a um modo de vida estritamente subordinado a uma leitura literal dos mandamentos, a uma prática rígida da religião entendida como um código do lícito e do ilícito. A sua obsessão é traçar uma linha de demarcação entre os "verdadeiros" e "falsos" crentes, privilegiando o rigorismo legalista e ritualista, a exteriorização da religião, em vez da interiorização dos seus ensinamentos, o separatismo sectário. Esta leitura da religião como código do lícito e do ilícito é uma verdadeira caricatura da religião, porque deixa de fora a sua essência, que é a sua mensagem ética. O monoteísmo conduz a isto? Não necessariamente. Pode conduzir ou não, depende da leitura e da interpretação que se faz, mas o que é certo é que não há uma relação de causa e efeito entre as duas realidades. 
Em segundo lugar, para o fundamentalismo religioso, Deus é César. O fundamentalismo recusa o espaço cultural autónomo, recusa a validade da experiência humana, histórica, social, cívica, artística, científica, tecnológica independente da religião. Sonha e luta pela instauração da lei divina sobre a terra - naturalmente por si interpretada - e defende a ocupação, por Deus, do terreno político. Tem a nostalgia de uma sociedade regida exclusivamente segundo as regras do direito divino, na qual a fusão entre o Estado, o direito e a religião é total. O monoteísmo leva a isto? Não necessariamente. Pode levar ou não, e há exemplos na história de uma coisa e de outra, mas o que é certo é que não há uma relação de causa e efeito entre as duas realidades.

Em terceiro lugar, o fundamentalista considera-se iluminado pela luz divina e investido de uma missão transcendente e, portanto, acha-se com o direito de recorrer a todos os meios, inclusive aos mais violentos, para impor a lei que ele considera de Deus sobre a terra. Reclamando-se de uma liberdade e de um direito que nega aos outros, considerando-se detentor da verdade, encontra aí a justificação para a acção violenta, individual ou colectiva. É por isso que o terreno fundamentalista é um terreno favorável ao desenvolvimento do terrorismo. É aí que o terrorismo vai recrutar os seus actores. Nem todos os fundamentalistas são terroristas, mas todos os terroristas são fundamentalistas. Yigal Amir, o assassino de Itzhak Rabin, era um estudante universitário que afirmou mais tarde: "Foi Deus que me guiou o braço".

Finalmente, e contrariamente a ideias preconcebidas, os fundamentalistas não provêm das camadas mais atrasadas da sociedade, não são nem camponeses, nem idosos, nem analfabetos. São em geral urbanos, com um relativo grau de instrução, que sabem utilizar muito bem as tecnologias de manipulação de massas. São muitas vezes detentores de diplomas e de profissões liberais que utilizam ao serviço dos seus movimentos. Porquê? Pela simples razão de que são eles que produzem as ideias e normalmente o fundamentalismo é a transformação da religião em ideologia.

Nem sempre todas estas componentes co-existem: por vezes, o fundamentalista é apenas o indivíduo que privilegia uma leitura rígida e literal dos fundamentos religiosos e não procura impô-los, nem à escala da sociedade, nem aos outros. Mas, de uma forma geral, define-se um fundamentalista pelas características acima referidas. 
Para terminar, diria apenas que não há uma relação de causa e efeito entre monoteísmo e fundamentalismo. Como tentei demonstrar, este é produto da transformação da religião numa ideologia, ou seja, de uma leitura dogmática dos preceitos religiosos interpretados à luz de uma visão política e ideológica. Estes tornam-se, assim, um fim em si mesmo, em vez de serem um guia para o comportamento ético. O fundamentalismo é estimulado pelo fracasso das ideologias laicas do século xx e pela modernização acelerada, destruindo identidades e valores, não pelo monoteísmo.

Apesar de minoritário, o fundamentalismo tem causado um mal profundo, nomeadamente levando ao afastamento da religião de numerosas pessoas e também opondo-se a qualquer tentativa de renovação religiosa.

Falámos até agora de um fundamentalismo religioso. Mas é bom referir que também existe um fundamentalismo laico ou laicista que também pode ser violento e que, mesmo sem o ser, é antidemocrático, redutor da liberdade individual e colectiva e que também procura impor a sua visão ideológica do mundo contra o que considera ser o "ópio do povo”. É contra ambos os fundamentalismos, aliás contra todos os fundamentalismos, que nos devemos insurgir e preocupar. Não contra o monoteísmo. 